\title{
Effects of fennel seed supplementation of ration on performance, egg quality, serum cholesterol, and total phenol content of egg yolk of laying quails
}

\author{
Kadir Emre Buğdaycı ${ }^{1 *}$, Fatma Karakaş Oğuz¹, Mustafa Numan Oğuz¹, Eren Kuter ${ }^{2}$ \\ ${ }^{1}$ Mehmet Akif Ersoy Universitesi, Veterinary Faculty, Animal Nutrition and Nutritional Diseases Department, Burdur, Turkey. \\ ${ }^{2}$ Adnan Menderes Universitesi, Veterinary Faculty, Animal Nutrition and Nutritional Diseases Department, Aydin, Turkey.
}

\begin{abstract}
The objective of this research was to evaluate the effects of fennel seed (Foeniculum vulgare Mill.) supplementation of ration on performance, egg quality, and serum cholesterol of laying quails during an eight-week period. For this purpose, 96 quail (Coturnix coturnix japonica) of 16 weeks of age were evenly separated into one control group and three treatment groups. Each group was divided into four replicates, each containing six quail. The fennel seeds (Foeniculum vulgare) were added to the diets of the first, second, and third treatment groups at levels of $0.3,0.6$, and $0.9 \%$, respectively. No significant effect of dietary fennel seed supplementation was recorded on body weight, feed intake, egg production, and egg weight. Feed efficiency ( $\mathrm{kg}$ feed per $\mathrm{kg}$ egg) of the $0.6 \%$ treatment group was negatively affected by fennel seed supplementation; however, kilogram of feed:dozen egg ratio was not affected when compared with the control group. The effects of dietary treatments on shape index, albumen height, albumen index, Haugh unit, yolk index, yolk colour, blood cholesterol level, and total phenol content of egg yolk had no significance. Dietary fennel seed do not affect the egg quality and blood cholesterol level of laying quail. The amount of $0.3,0.6$, and $0.9 \%$ dietary fennel seed supplementation do not have any adverse effect on performance and egg quality of laying quail.
\end{abstract}

Key Words: herbal additive, layer, mediterranean seed, phenolics

\section{Introduction}

Many countries have banned the use of antibiotics as performance and health enhancer for animals for the last decades. Natural additives such as botanicals, herbs, and seeds started to be investigated and took their place in the markets separately or as mixtures. However, their optimum doses and action mechanisms should be clarified. Besides, lots of other local herbs have been on hold for determination of their effects on animal production. Fennel seed is one of the traditionally used agricultural products in the Mediterranean region for gastrointestinal effects.

Austria and its neighbours traditionally use Fennel (Foeniculum vulgare) to avoid gastrointestinal problems such as colic and flatulence (Franz et al., 2010). Capillaceum, one of the two subspecies (the other is piperitum) of this

Received: September 19, 2017 Accepted: November 30, 2017

*Corresponding author: kebugdayci@mehmetakif.edu.tr

Copyright (C) 2018 Sociedade Brasileira de Zootecnia. This is an Open Access article distributed under the terms of the Creative Commons Attribution License (http://creativecommons.org/licenses/by/4.0/), which permits unrestricted use, distribution, and reproduction in any medium, provided the original work is properly cited. herb, has three varieties (dulce, vulgare, and azoricum). The dulce variety is sweet, the vulgare variety is bitter, and both of them grow wild (Díaz-Maroto et al., 2005). These two varieties exist in and around Burdur, the place of the study, where the Mediterranean climate dominates. Gastrointestinal relieving effects of fennel can be summarised as carminative, laxative, antispasmodic, and stimulant on abdominal pain. Briefly, fennel is used for discomforts of intestines and colon (Anonymous, 2015). About 50 to 60 percent of the oil in Foeniculum vulgare is Anetol (Saki et al., 2014). A study on the antibacterial effect of crude protein extract of fennel reported that the extract had an inhibition effect on Staphylococcus aureus, Escherichia coli, Pseudomonas aeruginosa, and Proteus vulgari (Akeel et al., 2014). Some studies have reported antimicrobial activities of fennel essential oils (Diao et al., 2014; Açıkgöz et al., 2017). Özbek et al. (2004) stated that dietary fennel essential oil acts as a hepatoprotective for liver fibrosis in rat models. Some others noted that fennel fruit methanolic extract (Choi and Hwang, 2004) and fennel fruit essential oil (Salami et al., 2016) may reduce the risk of inflammation-related diseases and have antimicrobial effect related with the content of trans-anathole. Besides these, some studies have stated that fennel seeds have antioxidant 
effects (Oktay et al., 2003; Rani and Meena, 2014). Fennel seed essential oil can also be an alternative to commercial insecticides (Zoubiri et al., 2014). Digilio et al. (2008) notified that when compared with the other Mediterranean essential oils produced from fennel, anise and basil have strong insecticidal activity. In addition, Pavela et al. (2016) declared that Czech fennel provides high yield and is effective in the development of botanical insecticides.

There are some rare studies about the use of fennel seeds in poultry diets in recent years, which have focused on the performance of broilers (Mohammed and Abbas, 2009; Ragab et al., 2013; Saki et al., 2014), broiler breeders (Kazemi-Fard et al., 2013), turkeys (Bhaisare and Thyagarajan, 2012), and growing Japanese quails (Mahmud, 2014). Çabuk et al. (2014) noted that using a mixture of essential oils, including fennel essential oil, for laying quails and laying hens at the hot summer seasons improved feed efficiency. Besides, Nasiroleslami and Torki (2010) revealed that dietary fennel essential oil decreased Haugh unit and improved eggshell weight and thickness in laying hens.

Dietary herbal additives can manipulate serum cholesterol due to their total phenolic ingredients. Andrews et al. (1968) stated that egg cholesterol stems from serum cholesterol. There may be a correlation between blood serum and egg yolk cholesterol. Narahari et al. (2005) reported that dietary garlic or basil leaves $(5 \mathrm{~g} / \mathrm{kg})$ in laying hens had a reducing effect on both serum and egg yolk cholesterol and had a better antioxidant effect. Ingredients of active components of poultry feed from herbs can be transferred to egg yolk, and eggs can be enriched by phytonutrients (Benakmoum et al., 2013). The phenolic acids of fennel seeds could be passed into egg yolk with other fat-soluble compounds. Thus, the study will also potentially specify the influence of dietary fennel seed on total egg yolk phenolic compounds of laying quail.

\section{Material and Methods}

The experiment with animals was performed and approved (case no. 58/2014) by the local ethics committee. The trial was conducted in the province of Burdur, located at $37^{\circ} 42^{\prime} \mathrm{N}$ latitude and $30^{\circ} 16^{\prime} \mathrm{E}$ longitude.

In the study, 96 quail (Coturnix coturnix japonica) of 16 weeks old were used. All groups were composed of 24 animals. Four subgroups of all groups, each containing six quail, were formed. Quail were kept in cages $(45 \times 50 \times$ $22 \mathrm{~cm}$ ) in department facility with a $20 / 4 \mathrm{~h}$ lighting period. During the eight weeks of the study, water and feed were supplied ad libitum. The fennel seeds (Foeniculum vulgare Mill.) were used in the diets of the three treatment groups at levels of $0.3,0.6$, and $0.9 \%$, respectively (Table 1 ).

The nutrient composition of fennel seed and basal diet were formulated according to AOAC (1990). The ingredients of laying quail diet were formulated $(200 \mathrm{~g} / \mathrm{kg}$ crude protein and $2900 \mathrm{kcal} / \mathrm{kg}$ metabolisable energy) using the software of Selçuk University Veterinary Faculty, Konya, Turkey, based on NRC (1994) nutrient recommendation for Japanese quail. During this period, water and feed were provided ab libitum. Titus and Fritz (1971) equation was used to calculate metabolisable energy levels of all rations.

Each quail was individually weighed both at the beginning and end of the study with the help of a precision balance (Model: HGM-20K-ER8412, 1-g sensitivity, UWE CO, Taipei-Taiwan). Any mortality observed was recorded. Dry matter of excreta was determined biweekly in all groups. Fort his purpose faeces of all groups were collected during $24 \mathrm{~h}$ and dried in $105^{\circ} \mathrm{C}$ incubator.

During the study, eggs were collected daily and egg production was calculated on hen-day basis. The eggs of all groups were collected every week - in the last two days of each week - and weighed individually with a balance Model CP224S-14105100, with $0.1 \mathrm{mg}$ sensitivity, Sartorius AG, Gottingen-Germany). Feed intake was calculated as g per day per quail by using weekly records. Feed efficiency ( $\mathrm{g}$ feed per g egg and $\mathrm{g}$ feed per dozen eggs) was calculated.

For the egg internal quality, eight eggs laid, in total, were randomly collected from 09:00 to 12:00 $\mathrm{h}$ from each group (two eggs from each replicate) on the 2nd, 4th, 6th, and 8th weeks of the study (a total of 32 eggs per group during the study). All collected eggs were weighed individually. Their shape index was calculated by using the following formula:

Shape index $=($ egg width $/$ egg length $) \times 100($ Anderson et al., 2004).

Eggs were broken onto a glass table individually. The height of the yolk and albumen was quantified with a micrometer (Mitutoyo, no. 2050S-19, 0.01-20 mm; Kawasaki, Japan). Egg internal quality parameters were calculated with these measurements by using the following equations, respectively: [yolk index $=$ (yolk height $/$ yolk diameter $) \times 100$; albumen index $=($ albumen height $/$ average of albumen length and albumen width) $\times 100$; Haugh unit = $100 \times \log$ (albumen height $+7.57-1.7 \times($ egg weight $) 37$ ] (Card and Nesheim, 1972). Egg yolk colour of treated eggs were scored by using Roche yolk colour fan (Vuilleumier, 1969) on a glass plate. 
Table 1 - Ingredients of basal diet and chemical composition of diets of control and treatment groups

\begin{tabular}{|c|c|c|c|c|c|c|}
\hline \multirow{2}{*}{ Ingredient ( $\mathrm{g} / \mathrm{kg}$ as fed) } & \multirow{2}{*}{ Basal diet } & \multirow{2}{*}{ Analysed composition ( $\mathrm{g} / \mathrm{kg}$ as fed) } & \multicolumn{4}{|c|}{ Treatment group } \\
\hline & & & Control & $0.3 \%$ & $0.6 \%$ & $0.9 \%$ \\
\hline Corn & 444.5 & Crude protein & 196.5 & 191.6 & 196.1 & 194.6 \\
\hline Wheat & 70 & Ether extract & 84.9 & 87.0 & 84.0 & 84.0 \\
\hline Soybean meal (48.5\%) & 180 & Crude fibre & 34.0 & 32.6 & 38.6 & 33.0 \\
\hline Full fat soya (37\%) & 100 & Crude ash & 121.3 & 107.3 & 98.3 & 99.2 \\
\hline Sunflower meal (32\%) & 90 & Dry matter & 923.2 & 920.7 & 921.5 & 919.9 \\
\hline Vegetable oil & 30 & & & & & \\
\hline DCP & 14 & Calcutated composition & & & & \\
\hline Limestone & 64 & Metabolisable energy $(\mathrm{MJ} / \mathrm{kg})^{2}$ & 11.49 & 11.69 & 11.70 & 11.76 \\
\hline Salt & 3 & Lysine (g/kg) & 10.9 & 10.9 & 10.9 & 10.9 \\
\hline Vitamin-mineral complex ${ }^{1}$ & 2.5 & Methionine + cystine $(\mathrm{g} / \mathrm{kg})$ & 7.9 & 7.9 & 7.9 & 7.9 \\
\hline DL-methionine & 1 & & & & & \\
\hline L-lysine & 1 & & & & & \\
\hline
\end{tabular}

After the collection of eggs, internal and external parameters were recorded within $24 \mathrm{~h}$. All the eggs were evaluated by using their own weights individually. On the last day of the study, two quail from each replicate (eight quails from each group) were randomly slaughtered by jugular venipuncture. Blood was gathered during the slaughtering time. Blood samples were centrifuged at $3000 \times g$ for $10 \mathrm{~min}$ individually. Serum was separated and stored at $-20{ }^{\circ} \mathrm{C}$ to indicate cholesterol by Autoanalyser (Model: Gesan-Chem200, No:1102422, Campobello-Italy) using its commercial kit (Monoreagent-LR-C2230150V).

To determine the total phenols in egg yolk, liyophilised yolk sample (1 g) was mixed with $1 \mathrm{M} 80: 20$, V/V methanol/ $\mathrm{HCl}(10 \mathrm{~mL})$, mixture adjusted to $\mathrm{pH}=1.5$. The mixture was blended with a vortex for $2 \mathrm{~min}$ and centrifuged at $6000 \times \mathrm{g}$ for $10 \mathrm{~min}$ at $4{ }^{\circ} \mathrm{C}$. Supernatant was evaporated with rotaryevaporator at $35{ }^{\circ} \mathrm{C}$. The residue was reconstituted by using $1 \mathrm{~mL}$ methanol and then filtered. To determine the total phenolic content of egg yolks, Folin Ciocalteu was used. To that end, $1.5 \mathrm{~mL}$ of $20 \%$ sodium carbonate $\left(\mathrm{Na}_{2} \mathrm{CO}_{3}\right)$ and $0.5 \mathrm{~mL}$ of the Folin Ciocalteu reagent were mixed with $0.1 \mathrm{~mL}$ of the sample. The mixture was made up to $10 \mathrm{~mL}$ and allowed to stand at room temperature for $2 \mathrm{~h}$. Folin Ciocalteu reagent was used to determine total phenolic content of fennel seeds. Briefly, $300 \mu \mathrm{L}$ of plant extract $(1 \mathrm{~g}$ fennel seed, $100 \mathrm{~mL}$ methanol, $150 \mathrm{rpm}, 3 \mathrm{~h}$ ) were thoroughly mixed with $1.5 \mathrm{~mL}$ of freshly diluted Folin Ciocalteu reagent $(1 \mathrm{~N})$, to which $1.2 \mathrm{~mL}$ of sodium carbonate solution $(7.5 \%)$ was added, and the mixture was incubated for $30 \mathrm{~min}$ in the dark. The two absorptions were measured at $760 \mathrm{~nm}$, using a spectrophotometer (PerkinElmer Lambda35-UV/ VIS-Spectrometer, no. 502S11122701, Singapore). The phenolic concentration was denoted as $\mathrm{mg}$ of gallic acid equivalents (GAE) per g egg yolk in all treatment groups and per g fennel seed dry matter (Singleton and Rossi, 1965; Benakmoum et al., 2013; Tupe et al., 2013).

Software SPSS 18.0 (SPSS Inc. Chicago, USA) was used for statistical analyses. Data was analysed for normal distribution by using the Kolmogorov-Smirnov test. Data was tested with One-way ANOVA to compare the differences in parameters among groups. Duncan's multiple range test was used to analyse the significance of mean differences among groups. All quality characteristics of eggs were determined after adjusting their weights. Results were shown as marginal means with their standard errors. Statistical significance was accepted at $\mathrm{P}<0.05$ (Dawson and Trapp, 2001).

\section{Results}

Analysis results of fennel seed in the present study were $92.65 \%$ dry matter (DM), $8.05 \%$ crude ash, $14.92 \%$ crude protein, $12.07 \%$ crude oil, $6.91 \%$ crude fibre, and $0.072 \mathrm{mg}$ gallic acid equivalent/g DM total phenolic compounds.

Initial and final body weights of quail had no significance (Table 2). No significant effect of dietary fennel seed supplementation was recorded on body weight, feed intake, hen day egg production, and egg weight of laying quail. The feed efficiency ( $\mathrm{kg}$ feed per $\mathrm{kg}$ egg) of the $0.6 \%$ treatment group was negatively affected 
by dietary fennel seed $(\mathrm{P}<0.05)$; however, $\mathrm{kg}$ feed per dozen egg ratio was not affected when compared with the control group (Table 3). Throughout the experiment, two quail from the $0.6 \%$ treatment group and two quail from the $0.9 \%$ treatment group died naturally (four quail in total). Total mortality of the study was calculated as $2.08 \%$.

Average values of egg shape index, albumen height, albumen index, Haugh unit, yolk index, and egg yolk colour of egg were not significantly affected in all treatment groups when compared with the control group (Table 4). Dietary treatments had no significant effect on serum levels of cholesterol, total phenolic compounds of egg yolk, and dry matter of excreta when compared with control (Table 5).

\section{Discussion}

Dietary fennel seed did not affect feed intake ( $P>0.05$ ), while treatment groups of 0.6 and $0.9 \%$ were numerically higher. This result is similar to the findings of Mohammed and Abbas (2009), who worked on fennel seeds for broilers, and the results of Nasiroleslami and Torki (2010), who worked on essential oils of fennel for laying hens. There are also similar reports on feed intake by using dietary fennel essential oil including mixture for laying quail (Çabuk et al., 2014), laying hens in the summer season (Çabuk et al., 2006), and quail breeders (Olgun and Yildiz, 2014). Besides these, Kaya et al. (2013) reported that dietary fennel oil, including plant extract

Table 2 - Effects of dietary treatments on initial and final body weights of laying quail (mean $\pm \mathrm{SE}$ )

\begin{tabular}{|c|c|c|c|c|c|}
\hline & \multicolumn{4}{|c|}{ Dietary treatment } & \multirow{2}{*}{$\mathrm{P}$-value } \\
\hline & Control & $0.3 \%$ & $0.6 \%$ & $0.9 \%$ & \\
\hline Initial body weight (g) & $268.70 \pm 5.06$ & $268.25 \pm 5.92$ & $269.33 \pm 6.29$ & $269.16 \pm 4.98$ & 0.999 \\
\hline Final body weight (g) & $267.95 \pm 5.08$ & $267.41 \pm 6.13$ & $270.00 \pm 6.30$ & $272.54 \pm 4.69$ & 0.916 \\
\hline
\end{tabular}

No significant differences among groups $(\mathrm{P}>0.05)$.

Table 3 - Effects of dietary treatments on performance of laying quail (mean $\pm \mathrm{SE}$ )

\begin{tabular}{|c|c|c|c|c|c|}
\hline & \multicolumn{4}{|c|}{ Dietary treatment } & \multirow{2}{*}{ P-value } \\
\hline & Control & $0.3 \%$ & $0.6 \%$ & $0.9 \%$ & \\
\hline Feed intake (g/day per quail) & $34.42 \pm 0.59$ & $33.88 \pm 1.33$ & $36.88 \pm 0.38$ & $35.80 \pm 0.99$ & 0.134 \\
\hline Egg production $(\%)$ & $85.41 \pm 4.90$ & $93.30 \pm 2.49$ & $96.64 \pm 1.65$ & $91.74 \pm 2.16$ & 0.123 \\
\hline Egg weight $(g)$ & $13.64 \pm 0.09$ & $13.54 \pm 0.30$ & $13.13 \pm 0.27$ & $13.81 \pm 0.18$ & 0.249 \\
\hline Feed efficiency (kg feed per kg egg) & $2.52 \pm 0.05 b$ & $2.50 \pm 0.06 \mathrm{~b}$ & $2.81 \pm 0.06 \mathrm{a}$ & $2.59 \pm 0.09 b$ & 0.031 \\
\hline Feed efficiency (kg feed per dozen egg) & $0.487 \pm 0.023$ & $0.435 \pm 0.011$ & $0.458 \pm 0.012$ & $0.466 \pm 0.014$ & 0.222 \\
\hline
\end{tabular}

$\mathrm{a}, \mathrm{b}$ - Means within a line followed by different letters differ significantly $(\mathrm{P}<0.05)$.

Table 4 - Effects of dietary treatments on egg traits of laying quail (mean $\pm \mathrm{SE})$

\begin{tabular}{|c|c|c|c|c|c|}
\hline & \multicolumn{4}{|c|}{ Dietary treatment } & \multirow{2}{*}{ P-value } \\
\hline & Control & $0.3 \%$ & $0.6 \%$ & $0.9 \%$ & \\
\hline Weight of treated eggs (g) & $13.80 \pm 0.21 \mathrm{a}$ & $13.80 \pm 0.21 \mathrm{a}$ & $12.98 \pm 0.21 \mathrm{~b}$ & $13.59 \pm 0.08 \mathrm{a}$ & 0.037 \\
\hline Crude ash of egg shell (g) & $0.93 \pm 0.01$ & $0.93 \pm 0.01$ & $0.90 \pm 0.01$ & $0.94 \pm 0.01$ & 0.278 \\
\hline Shape index (\%) & $76.70 \pm 0.41$ & $77.15 \pm 0.34$ & $76.01 \pm 2.48$ & $77.76 \pm 0.62$ & 0.332 \\
\hline Albumen height (mm) & $4.43 \pm 0.14$ & $4.51 \pm 0.09$ & $4.58 \pm 0.19$ & $4.45 \pm 0.12$ & 0.882 \\
\hline Albumen index $(\%)$ & $9.86 \pm 0.43$ & $10.24 \pm 0.34$ & $10.17 \pm 0.40$ & $10.68 \pm 0.32$ & 0.904 \\
\hline Yolk index $(\%)$ & $43.10 \pm 0.88$ & $43.62 \pm 1.61$ & $44.16 \pm 0.76$ & $45.35 \pm 0.39$ & 0.134 \\
\hline Haugh unit & $87.63 \pm 0.80$ & $87.96 \pm 0.53$ & $88.70 \pm 0.81$ & $87.68 \pm 0.65$ & 0.701 \\
\hline Egg yolk colour ${ }^{1}$ & $10.68 \pm 0.16$ & $10.83 \pm 0.11$ & $10.98 \pm 0.21$ & $10.87 \pm 0.16$ & 0.656 \\
\hline
\end{tabular}

${ }^{1}$ Roche colour scores are based upon Roche Colour Fan Edition (1965).

$\mathrm{a}, \mathrm{b}$ - Means within a line followed by different letters differ significantly $(\mathrm{P}<0.05)$.

Table 5 - Effects of dietary treatments on serum cholesterol, total phenols of egg yolk, and dry matter of excreta of laying quail $($ mean \pm SE)

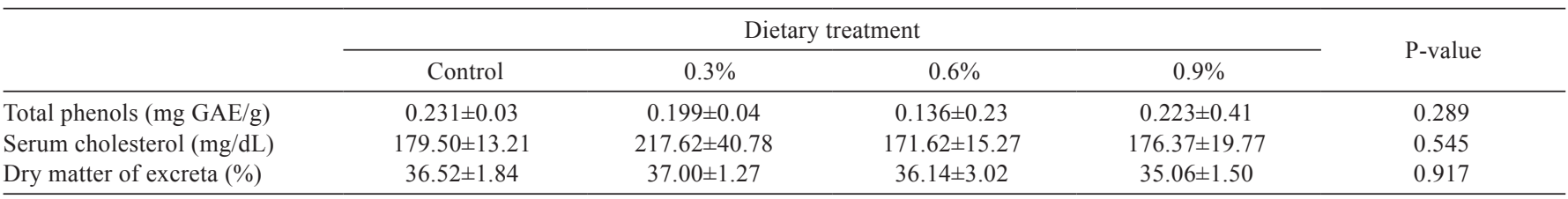

No significant differences among groups $(\mathrm{P}>0.05)$ 
mixture, did not affect feed intake of laying hens. However, Saki et al. (2014) reported that dietary $0.5 \%$ fennel seeds increased feed intake of broilers. Wenk (2003) stated that botanicals can alter feed intake and endogenous secretions in monogastric animals. On the other hand, Schone et al. (2006) stated that dietary $100 \mathrm{mg} / \mathrm{kg}$ fennel essential oil decreased feed intake of weaned pigs. Recently, Costa et al. (2013) reported that dietary phytogenics can be limited to the palatability of the diets of monogastric animals. Body weight, egg production, and egg weight were not affected by dietary treatments. This result is similar to several studies on layer hens (Kaya et al., 2013) and quail breeders (Olgun and Yıldız, 2014). The study of Çabuk et al. (2014) also revealed similar findings on egg weight by using dietary fennel essential oil including mixture for laying hens at the summer season. However, the results of feed efficiency ( $\mathrm{kg}$ feed per kg egg) are not similar. While Olgun and Yildiz (2014) reported no significance for feed efficiency, Çabuk et al. (2014) and Çabuk et al. (2006) had better results. These conflicting results may be due to the amount of active fennel components (trans-anethole) of dietary products and product dosages in the rations.

Egg production of control and 0.3, 0.6, and $0.9 \%$ treatment groups were 85.41, 93.30, 96.64, and 91.74, respectively. The numerical differences in egg production in the groups were not significant when compared with the control group. The result of egg production is similar to results of Nasiroleslami and Torki (2010) and Olgun and Yıldız (2014). However, dietary $50 \mathrm{mg} / \mathrm{kg}$ fennel extract increased the egg production of broiler breeders (KazemiFard et al., 2013). Results similar to these were presented by some studies which reported that dietary fennel essential oil included mixture that increased the egg production of laying hens in summer season (Çabuk et al., 2006), in long term (Bozkurt et al., 2012), and laying quail (Çabuk et al., 2014). These differences may be caused by the composition of rations as well as the content of dietary active ingredients (trans-anethole) of fennel seed and the amounts of active ingredient and composition of essential oil mixtures.

Dietary fennel seed did not affect average values of egg shape index, albumen height, albumen index, Haugh unit, yolk index, and yolk colour. The results of egg quality traits were similar to those of Nasiroleslami and Torki (2010) study, except for Haugh unit, which were lower for hens receiving $300 \mathrm{mg}$ fennel essential oil compared with the control group. However, Kazemi-Fard et al. (2013) reported that dietary 50 and $100 \mathrm{mg} / \mathrm{kg}$ fennel extract had no effect on Haugh unit of eggs, which complies with our results. Similarly, Bozkurt et al. (2012) declared that fennel essential oil containing commercial oil mixture supplementation to diet of laying hens did not affect external egg quality and albumen height in the long term. In the present study, the yolk colour was not affected by dietary fennel seed supplementation. This result is also similar to results of Kazemi-Fard et al. (2013). Kaya et al. (2013) reported that dietary herbal mixture can be helpful to enhance shell stiffness and thickness. In the present study, the crude ash of eggshell was not affected by dietary fennel seed.

The inclusion of the different amounts of dietary fennel seed did not significantly affect total phenol content of egg yolks when compared with the control group (Figure 1). Benakmoum et al. (2013) reported that increasing the levels of dietary dried tomato peel $(3,7,10$, and $13 \%)$ increased total phenol contents in egg yolk of laying hens. Thus, this difference may be caused by the amounts of dietary fennel seed in the ration and the difference between total phenolic contents of fennel seed and tomato peels.

Dietary $15 \%$ fennel seeds reduced blood cholesterol levels in rats fed a high-cholesterol diet (Özbek et al., 2006). Similarly, Oulmouden et al. (2014) reported that dietary fennel extract reduces blood cholesterol levels of mice. In broilers, dietary $100 \mathrm{ppm}$ fennel essential oil decreased blood cholesterol levels; however, fennel essential oil containing essential oil mixtures in dietary dosages of 100 and $200 \mathrm{ppm}$ did not affect blood cholesterol levels (Belenli et al., 2015). Dietary 750 and $1000 \mathrm{mg} / \mathrm{kg}$ fennel oil, including plant extract mixture, did not affect cholesterol and triglyceride concentrations of yolk and serum of laying hens (Kaya et al., 2013). In the present study, dietary treatments of fennel seed did not affect blood cholesterol levels of laying quail. These differences may be caused by the ration combinations, species of animals, and dietary levels of active ingredients of fennel seeds.

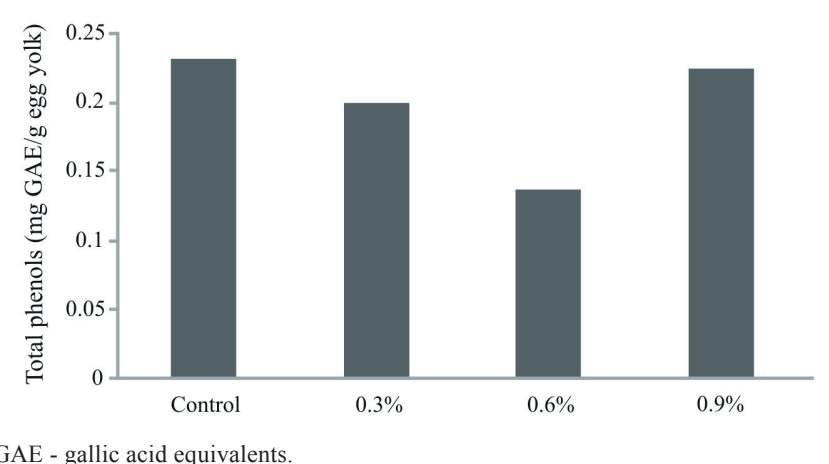

Figure 1 - Total phenol content of egg yolk. 


\section{Conclusions}

In the present study, expected effects of fennel seed active ingredients is not observed in laying quails. The performance, egg quality, and blood cholesterol parameters are not altered by the low levels of fennel seed supplementation. Because of the unknown side effects of dietary fennel seed on laying quails, treatment groups were designed with low and close levels of fennel seed. On the other hand, higher levels of fennel seed supplementation could be altered due to its phytoactive ingredients such as fatty acids and phenolic compounds.

\section{Acknowledgments}

The authors would like to thank Asst. Prof. Dr. Hale Seçilmiş Canbay for her scientific support.

\section{References}

Açıkgöz, M. A.; Kara, Ș. M.; Aruç, C. and Ay, E. 2017. Morphogenetic, ontogenetic and diurnal variability in antimicrobial activity of bitter fennel (Foeniculum vulgare Miller var. vulgare) essential oil. Indian Journal of Pharmaceutical Education and Research 51:190-193.

Anderson, K. E.; Tharrington, J. B.; Curtis, P. A. and Jones, F. T. 2004. Shell characteristics of eggs from historic strains of single comb white leghorn chickens and relationship of egg shape to shell strength. International Journal of Poultry Science 3:17-19.

Andrews, J. W.; Wagstaff, R. K. and Edwards, H. M. 1968. Cholesterol metabolism in the laying fowl. American Journal of Philology 214:1078-1083.

Anonymous. 2015. Fennel. In: Aromatic and medicinal plants index. Purdue University. WebMD. Available at: $<\mathrm{https} / / \mathrm{www}$. hort.purdue.edu/newcrop/med-aro/factsheets/FENNEL.html>. Accessed on: May 5, 2015.

AOAC - Association of Official Analytical Chemists. 1990. Official methods of analysis of the association of official analytical chemists. 14th ed. Association of Official Analytical Chemists, Arlington, VA.

Akeel, R. A.; Al-Sheikh, Y.; Mateen, A.; Syed, R.; Janardhan, K. and Gupta, V. C. 2014. Evaluation of antibacterial activity of crude protein extracts from seeds of six different medical plants against standard bacterial strains. Saudi Journal of Biological Sciences 21:147-151.

Belenli, D.; Udum, D.; Cengiz, S. Ş. and Polat, Ü. 2015. Influence of various volatile oils as a dietary supplement on biochemical and performance parameters in broilers. Journal of Biodiversity and Environmental Sciences 9:47-55.

Benakmoum, A.; Larid, R. and Zidani, S. 2013. Enriching egg yolk with carotenoids \& phenols. International Science Index, Nutrition and Food Engineering 7(7). waswt.org/Publication/16282.

Bhaisare, D. B. and Thyagarajan, D. 2012. Effect of four herbal seeds on blood parameters in turkey poults. International Journal of Science and Research 3:235-240.

Bozkurt, M.; Küçükyılmaz, K.; Pamukçu, M.; Çabuk, M.; Alçiçek, A. and Çatl, U. 2012. Long-term effects of dietary supplementation with an essential oil mixture on the growth and laying performance of two layer strains. Italian Journal of Animal Science 11:23-28.
Choi, E. M. and Hwang, J. K. 2004. Antiinflammatory, analgesic and antioxidant activities of the fruit of Foeniculum vulgare. Fitoterapia 75:557-565.

Çabuk, M.; Bozkurt, M.; Alçiçek, A.; Çatlı, A. U. and Başer, K. H. C. 2006. Effect of a dietary essential oil mixture on performance of laying hens in the summer season. South African Journal of Animal Science 36:215-221.

Çabuk, M.; Eratak, S.; Alçicek, A. and Bozkurt, M. 2014. Effects of herbal essential oil mixture as a dietary supplement on egg production in quail. The Scientific World Journal, Article ID 573470, 4 pages. http://dx.doi.org/10.1155/2014/573470

Card, L. E. and Nesheim, M. C. 1972. Poultry production. 11th ed. Lea and Febiger, Philadelphia.

Costa, L. B.; Luciano, F. B.; Miyada, V. S. and Gois, F. D. 2013 Herbal extracts and organic acids as natural feed additives in pig diets. South African Journal of Animal Science 43:181-193.

Dawson, B. and Trapp, R. G. 2001. Basic and clinical biostatistics. 3rd ed. Lange Medical Books/McGraw-Hill Medical Publishing Division, N.Y.

Díaz-Maroto, M. C.; Díaz-Maroto, I. J.; Sánchez-Palomo, E. and Pérez-Coello, M. S. 2005. Volatile components and key odorants of fennel (Foeniculum vulgare Mill.) and thyme (Thymus vulgaris L.) oil extracts obtained by simultaneous distillation-extraction and supercritical fluid extraction. Journal of Agricultural and Food Chemistry 53:5385-5389.

Diao, W-R.; Hua, Q-P.; Zhang, H. and Xu, J-G. 2014. Chemical composition, antibacterial activity and mechanism of action of essential oil from seeds of fennel (Foeniculum vulgare Mill.). Food Control 35:109-116.

Digilio, M. C.; Mancini, E.; Voto, E. and De Feo, V. 2008 Insecticide activity of Mediterranean essential oils. Journal of Plant Interactions 3:17-23.

Franz, C.; Baser, K. H. C. and Windisch, W. 2010. Essential oils and aromatic plants in animal feeding - a European perspective. A review. Flavour and Fragrance Journal 25:327-340.

Kaya, A.; Kaya, H.; Macit, M.; Çelebi, Ş.; Esenbuğa, N.; Yörük, M. A. and Karaoğlu, M. 2013. Effects of dietary inclution of plant mixture and copper into layer diets on egg yield and quality, yolk cholesterol and fatty acid composition. Kafkas Universitesi Veteriner Fakultesi Dergisi 19:673-679.

Kazemi-Fard, M.; Kermanshahi, H.; Rezaei, M. and Golian, A. 2013. Effect of different levels of fennel extract and vit D3 on performance, hatchability and Immunity in post molted broiler breeders. Iranian Journal of Applied Animal Science 3:733-745.

Mahmud, H. A. 2014. Response of growing Japanese quail to different levels of fennel seeds meal. Egyptian Poultry Science Journal 34:795-807.

Mohammed, A. A. and Abbas, R. J. 2009. The effect of using fennel seeds (Foeniculum vulgare L.) on productive performance of broiler chickens International Journal of Poultry Science 8:642-644.

Nasiroleslami, M. and Torki, M. 2010. Including essential oils of fennel (Foeniculum vulgare) and Ginger (Zingiber officinale) to diet and evaluating performance of laying hens, white blood cell count and egg quality characteristics. Advances in Environmental Biology 4:341-345.

Narahari, D.; Michealraj, P.; Kirubakaran, A. and Sujatha, T. 2005. Antioxidant, cholesterol reducing, immunomodulating and other health promoting properties of herbal enriched designer eggs. p.194-201. In: Proceedings of the 11th European Symposium on the Quality of Eggs and Egg Products, Doorwerth, The Netherlands.

NRC - National Research Council. 1994. Nutrient requirements of poultry. 9th rev. ed. National Academy Press, Washington, DC. Available at: <www.nap.edu/openbook.php?record id=2114\&page=44>. Accessed on: Jan. 3, 2015. 
Oktay, M.; Gülçin, İ. and Küfrecioğlu, Ö. İ. 2003. Determination of in vitro antioxidant activity of fennel (Foeniculum vulgare) seed extracts. LWT - Food Science and Technology 36:263-271.

Olgun, O. and Yıldız, A. Ö. 2014. Effect of dietary supplementation of essential oils mixture on performance, eggshell quality, hatchability, and mineral excretion in quail breeders. Environmental Science and Pollution Research 21:13434-13439.

Oulmouden, F.; Noredine, G.; Morhit, M. E.; Benomar, H.; Daoudi, E. M. and Amrani, S. 2014. Hypolipidemic and anti-atherogenic efect of methanol extract of fenel (Foeniculum vulgare) in hypercholesterolemic mice. International Journal of Science and Knowledge 3:42-52.

Özbek, H.; Cengiz, N.; Him, A.; Uğraş, S.; Özgökçe, F. and Erdoğan, E. 2006. The study of the effects of Foeniculum vulgare P. Mill. (fennel) seeds on the blood cholesterol levels and some other blood paramaters in high cholesterol diet fed rats. Genel Tip Dergisi $16: 175-180$.

Özbek, H.; Ugras, S.; Bayram, I.; Uygan, I.; Erdogan, E.; Öztürk, A. and Huyut, Z. 2004. Hepatoprotective effect of Foeniculum vulgare essential oil: A carbon-tetrachloride induced liver fibrosis model in rats. Scandinavian Journal of Laboratory Animal Science 1:9-17.

Pavela, R.; Zabka, M.; Bednár, J.; Tríska, J. and Vrchotová, N. 2016. New knowledge for yield, composition and insecticidal activity ofessential oils obtained from the aerial parts or seeds of fennel (Foeniculum vulgare Mill.). Industrial Crops and Products 83:275-282.

Ragab, M. S.; Namra, M. M. M.; Aly, M. M. M. and Fathi, M. A. 2013. Impact of inclusion fennel seeds and thyme dried leaves in broiler diets on some productive and physiological performance during summer season. Egyptian Poultry Science Journal 33:197-219.

Rani, M. U. and Meena, R. 2014. Comparative study on antioxidant potential and phytochemical composition of cumin and fennel. Journal of Herbs, Spices and Medicinal Plants 20:245-255.
Saki, A. A.; Kalantar, M.; Rahmatnejad, E. and Mirzaaghatabar, F. 2014. Health characteristics and performance of broiler chicks in response to Trigonella foenum graecum and Foeniculum vulgar. Iranian Journal of Applied Animal Science 4:387-391.

Salami, M.; Rahimmalek, M.; Ehtemam, M. H.; Szumny, A.; Fabian, S. and Matkowski, A. 2016. Essential oil composition, antimicrobial activity and anatomical characteristics of Foeniculum vulgare Mill. fruits from different regions of Iran. TEOP 19:1614-1626.

Schone, F.; Vetter, A.; Hartung, H.; Bergmann, H.; Bietumpfel, A.; Richter, G.; Müller, S. and Breitschuh, G. 2006. Effects of essential oils from fennel (Foniculum aetheroleum) and caraway (Carvi aetheroleum) in pigs. Journal of Animal Physiology and Animal Nutrition 90:500-510.

Singleton, V. L. and Rossi, J. A. J. R. 1965. Colorimetry of total phenolics with phosphomolybdic-phosphotungstic acid reagents. American Journal of Enology and Viticulture 16:144-158.

Titus, H. W. and Fritz, J. C. 1971. Percentage multipliers for computing metabolizable energy values, for chickens, of some feedstuffs used in the feeding of poultry. p.295-298. In: The scientific feeding of chickens. 5th ed. Interstate, Danville, IL.

Tupe, R. S.; Kemse, N. G. and Khaire, A. A. 2013. Evaluation of antioxidant potentials and total phenolic contents of selected Indian herbs powder extracts. International Food Research Journal 20:1053-1063.

Wenk, C. 2003. Herbs and botanicals as feed additive in monogastric animals Asian-Australasian Journal of Animal Sciences 16:282-289.

Vuilleumier, J. P. 1969. The 'Roche Colour Fan' - An instrument for measuring yolk colour. Poultry Science 48:767-779.

Zoubiri, S.; Baaliouamer, A.; Seba, N. and Chamouni, N. 2014. Chemical composition and larvicidal activity of Algerian Foeniculum vulgare seed essential oil. Arabian Journal of Chemistry 7:480-485. 